Article

\title{
Sustainability Reporting at a New Zealand Public University: A Longitudinal Analysis
}

\author{
Yi An ${ }^{1}$, Howard Davey ${ }^{2}$ and Harun Harun ${ }^{3, *}$ \\ 1 College of Management, Ocean University of China, Qingdao 266100, China; rysonahn@hotmail.com \\ 2 Waikato Management School, University of Waikato, Hamilton 3240, New Zealand; hdavey@waikato.ac.nz \\ 3 Faculty of Business, Governance and Law, University of Canberra, Canberra, ACT 2615, Australia \\ * Correspondence: harun.harun@canberra.edu.au; Tel.: +61-2-6201-5960
}

Received: 25 July 2017; Accepted: 25 August 2017; Published: 28 August 2017

\begin{abstract}
This study examines the case of sustainability reporting by a New Zealand public university from a longitudinal perspective. Content analysis of the sustainability report for a five-year period is the primary research method. We observe that sustainability reporting by the case university excessively focuses on environmental reporting with a near absence of economic and social disclosures. Also, the results reveal that there is a generally upward trend for the reporting in the period, albeit the overall level is still low without any monetary disclosures in the report. Moreover, we find that the university does not follow any guidelines in its reporting. Based upon the results and findings, we provide some suggestions for universities to improve their sustainability reporting. This study contributes to the limited research with regard to sustainability reporting in the higher education sector, particularly from a longitudinal perspective. It is expected that this research would have some implications for academics and university sustainability policy makers.
\end{abstract}

Keywords: sustainability reporting; university; longitudinal; New Zealand

\section{Introduction}

It is often argued that the higher education sector should play a key role in disseminating the concept of sustainability since it is a central place to educate future leaders for various organizations [1,2]. In effect, a number of universities worldwide have made great efforts to integrate the concept of sustainability into their education, research, and community services in the recent decade [3]. These efforts would be beneficial to guide the future leaders to think and behave in a sustainable manner in a future career, and this would consequently promote the society as a whole to achieve the goal of sustainability.

Furthermore, a few universities in the world have attempted to report their sustainability related initiatives and activities through a stand-alone sustainability report or via the internet, so as to meet the increasing information demand from various stakeholders [4]. It is believed that the reporting of sustainability related information could assist universities legitimate their status as a public organization concerned with social and environmental issues in the communities where they operate $[3,5]$.

The aim of this study is to examine the extent and trend of sustainability reporting by a New Zealand public university (University of Canterbury) from a longitudinal perspective. We chose this university as a case because it is the only university to issue an external stand-alone sustainability report in a nation that prides itself on sustainability, and where this has become a part of its national culture. The results indicate that the current level of sustainability reporting by the case university is hard to be deemed sufficient, while it excessively focuses on environmental disclosures. However, the overall trend is increasing. Also, we notice that the university does not follow any relevant guidelines for its reporting. This may be a primary cause for the overall poor performance.

The contribution of this study is twofold. First, it contributes to the limited research with respect to sustainability reporting in the higher education sector, particularly from a longitudinal perspective. 
Second, this research provides some practical suggestions for universities to improve the level of sustainability reporting on the basis of the findings in the present study.

\section{Sustainability Reporting in the Higher Education Sector}

At present, sustainability reporting has been a common practice for commercial entities worldwide. There have been numerous studies investigating the state of sustainability reporting (or social and environmental reporting) in companies in varied national contexts or in a particular industrial sector for several decades [6-10]. Yet for relevant research in the public sector, it is still minor, albeit the number of studies is growing [11,12]. This position is not sensible as public sector organizations account for approximately $40 \%$ of total economic activities [13]. More specifically, when we search for literature regarding sustainability reporting in the high education sector, it is limited. That is not unexpected, as Alonso-Almeida et al. indicate that "the diffusion of SR (sustainability reporting) is still in its infancy in universities" [1] (p. 146). The unavailability of specific reporting guidelines for the sector may contribute to the state.

It is often recognized that the GRI (Global Reporting Initiatives) guidelines are the most widely accepted guidelines for sustainability reporting for organizations as it uses a holistic approach for reporting, which takes economic, social, and environmental dimensions into account [3]. Moreover, the GRI has developed guidelines for some specific sectors, such as energy and finance. In 2005, GRI released its Sector Supplement for Public Agencies (SSPA) that provides guidelines particularly for sustainability reporting of public sector organizations. The SSPA guidelines include six performance indicators particularly designed for the public agencies (namely "Public Policies and Implementation Measures") in addition to the general indicators relating to economic, social, and environmental aspects (that are classified into core and additional indicators in the framework) [14].

Previous studies have suggested that GRI guidelines including the SSPA are not often employed by public agencies for sustainability reporting, due to the shortage of professionals, resources, and relevant knowledge [12,15]. For the case of the university sector, the situation is worse owing to the specific characteristics of the sector in that its main business focuses on teaching, research, and community outreach. There are currently not any specific guidelines for the sector, including the SSPA framework, which does not give a full consideration as to the characteristics of the specific sector. In the circumstances, it is not surprising that sustainability reporting at universities is still in its "infancy" stage.

Nevertheless, pursuant to legitimacy theory, there is a social contract between the organization and the community where it operates. Within the contract, an organization should not only comply with societal expectations and norms in operation, but also seek to ensure that its operations are perceived to be consistent with the societal expectations and norms by various stakeholders in society [16,17]. In these circumstances, the organization would be deemed to be legitimate. According to Lindblom, information disclosure is an effective means for organizations to achieve legitimacy [18]. Due to the significance of sustainability, as well as the increasing demand of sustainability related information by various stakeholders, sustainability reporting would be helpful for universities, particularly those public universities, to legitimize their status in the community where they operate, and further to achieve a competitive advantage in raising funds from the government and other stakeholders [3].

\section{The Case in the Present Study}

The University of Canterbury (UC) was established in 1873, making it the second oldest university in New Zealand. It is one of the eight publically funded universities in the nation. The university is composed of five colleges: arts; education, health and human development; engineering; science; and, business and law. It offers undergraduate and postgraduate courses in more than 70 subjects, with approximately 12,000 students enrolled each year. UC has achieved a five star rating for overall excellence by the global higher education ranking agency QS since 2011, which made it the first 
university in New Zealand to achieve the honor. In the 2016-2017 QS world university rankings, it was ranked 217 overall, including 19 subjects ranked in the world's top 200.

As one of the leading universities in New Zealand, UC assigns a great importance to sustainability, and the related teaching and research. It has established a sustainability office, responsible for the sustainability issues on campus (for detailed roles of the sustainability office, please refer to the following link: http://www.sustain.canterbury.ac.nz/aboutoffice.shtml). Moreover, UC has attempted to report its sustainability initiatives and efforts, using the stand-alone sustainability report. As a matter of fact, UC is currently the only University in New Zealand issuing an external stand-alone sustainability report to the public. The university has published this report since 2011.

The sustainability office is accountable for the preparation and dissemination of the report. To date, there are five years' reports (2011-2015) available on its website [19-23]. However, the report is very environmentally concentrated, ignoring most economic and social disclosures. In effect, it may be more appropriate to call the report as an environmental report rather than a sustainability report at the present stage. Owing to the near absence of economic and social disclosures, this study tends to focus on examining the extent and trend of environmental reporting by the university, albeit we collect data from the so-called "sustainability report".

\section{Research Approach}

In this research, content analysis of the sustainability report for five years by UC is the primary research method. The method has been widely used in previous studies with respect to social and environmental reporting (or sustainability reporting), in both private and public organizations [24]. We developed an assessment framework that acts as an instrument for content analysis, principally based upon GRI guidelines (G4) and the characteristics of UC's sustainability reports. Because the sustainability report of UC is very environmentally concentrated, the developed framework focuses on the environmental aspects. In order to improve the validity of the framework, we also consulted with some experts (including three professors and a sustainability officer at universities) in the area for their suggestions via email.

The final framework consists of 15 environmental aspects, and each aspect includes a number of performance metrics (as illustrated in Table 1). In the course of the content analysis, we applied a binary dichotomous approach $(0 / 1)$ to code the absence/presence of each performance metric. The score was then aggregated for each aspect, and the total for each year, to determine the extent of reporting. This approach would be helpful to prevent subjectivity from explicit rules in the coding process $[3,25]$. Also, we coded the quality of disclosures in terms of the reporting type as shown in Table 2. It is often regarded that the type of reported information with "physical + monetary + descriptive" is the highest quality.

Table 1. The assessment framework.

\begin{tabular}{ll}
\hline \multicolumn{1}{c}{ Aspects } & \multicolumn{1}{c}{ Performance Metrics } \\
\hline Vision and strategy & 1. Statement of environmental vision and/or strategy \\
\hline \multirow{2}{*}{ Material } & $\begin{array}{l}\text { 1. Material used by volume or weight } \\
\text { 2. (Amount and/or percentage of) Material used that are recycled }\end{array}$ \\
\hline \multirow{2}{*}{ Energy } & $\begin{array}{l}\text { 1. Energy consumption by the organization } \\
\text { 2. Reduction of energy consumption }\end{array}$ \\
\multirow{2}{*}{ Water } & $\begin{array}{l}\text { 1. Total use of water } \\
\text { 2. Water sources and related ecosystems/habitats significantly } \\
\text { affected by use of water }\end{array}$ \\
& 3. (total volume and/or percentage of) Water recycled and reused \\
\hline
\end{tabular}


Table 1. Cont

\begin{tabular}{|c|c|}
\hline Aspects & Performance Metrics \\
\hline Landscape and biodiversity & $\begin{array}{l}\text { 1. Location and size of land owned, leased, managed in } \\
\text { biodiversity-rich habitats } \\
\text { 2. Description of significant impacts of activities and operations on } \\
\text { biodiversity in or around protected and sensitive areas } \\
\text { 3. Initiatives and outcomes to protect or restore habitats } \\
\text { 4. Number of LUCN red list and state conservation list species with } \\
\text { habitats in areas affected by university operations }\end{array}$ \\
\hline Emissions & $\begin{array}{l}\text { 1. Direct greenhouse gas emissions } \\
\text { 2. Indirect greenhouse gas emissions } \\
\text { 3. Reduction of greenhouse gas emissions } \\
\text { 4. Other Emissions and reduction }\end{array}$ \\
\hline Effluents and waste & $\begin{array}{l}\text { 1. Water discharge by type and destination, including } \\
\text { treatment method } \\
\text { 2. Total amount of waste by type and recycling } \\
\text { 3. Total amount of significant spills } \\
\text { 4. The amount of waste deemed hazards in terms of the Basel } \\
\text { Convention Annex I, II, III, VIII } \\
\text { 5. Water sources and related habitats significantly affected by } \\
\text { discharges of water and runoff }\end{array}$ \\
\hline Compliance & $\begin{array}{l}\text { 1. Statement of environmental compliance otherwise significant } \\
\text { fines and sanctions in monetary or non-monetary terms due to } \\
\text { non-compliance with environmental laws and regulations }\end{array}$ \\
\hline Transport & $\begin{array}{l}\text { 1. Significant environmental impacts of transportation used in } \\
\text { the university }\end{array}$ \\
\hline Overall & $\begin{array}{l}\text { 1. Total amount of environmental related expenditures and } \\
\text { investments by type }\end{array}$ \\
\hline Supplier environmental assessment & 1. Percentage of new suppliers screened using environmental criteria \\
\hline Environmental grievance mechanisms & $\begin{array}{l}\text { 1. Number of environmental related complaints received through } \\
\text { university formal grievance mechanisms }\end{array}$ \\
\hline Education & $\begin{array}{l}\text { 1. Environmental related education policies } \\
\text { 2. Environmental related degree programs } \\
\text { 3. Environmental related courses } \\
\text { 4. Environmental related scholarships/awards } \\
\text { 5. Environmental literacy assessment } \\
\text { 6. Non-curricular environmental education }\end{array}$ \\
\hline Research & $\begin{array}{l}\text { 1. Environmental related research policies } \\
\text { 2. Environmental related research centers/labs } \\
\text { 3. Environmental related research programs/projects } \\
\text { 4. Environmental related research funding } \\
\text { 5. Environmental related publications/outcomes }\end{array}$ \\
\hline Community engagement & $\begin{array}{l}\text { 1. Community activities and services } \\
\text { 2. Environmental related awards from communities } \\
\text { 3. Initiatives in service learning } \\
\text { 4. Initiatives in fair trade }\end{array}$ \\
\hline
\end{tabular}

Table 2. Quality of reported information.

\begin{tabular}{cc}
\hline Code & Reporting Type \\
\hline 1 & Descriptive \\
2 & Physical \\
3 & Physical + descriptive \\
4 & Monetary \\
5 & Monetary + descriptive \\
6 & Physical + monetary \\
7 & Physical + monetary + descriptive \\
\hline
\end{tabular}

In addition, to obtain a more in-depth comprehension with respect to the state of sustainability reporting at the university, we conducted some interviews with students, academics, and staff in the sustainability office. 


\section{Findings and Discussion}

Table 3 presents the reporting performance of the university for the five-year period. From the table, we can find that there is a generally upward trend for the reporting as the total number of reported metrics is from 11 in 2011 to 18 in 2015. It is noted that the best performance appears in 2013, with 20 reported environmental metrics. However, as we look at the weighting as to the number of reported metrics to the possible maximum for any individual year in the period, the result is disappointing since all the scores are below $50 \%$. That is, the university scored less than half that they could have in any individual year during the period, even for the year with the best performance (2013) they only scored $49 \%$ of the maximum potential. Therefore, we conclude that the overall performance of environmental reporting by the university is not good even though the overall reporting trend is increasing. The results are not surprising. As we analyzed the reports of the university for the five years, we observed that its reporting is quite discursive, and it did not follow any reporting guidelines, such as GRI and its SSPA.

Table 3. Reporting performance of the case university (2011-2015).

\begin{tabular}{lccccc}
\hline \multicolumn{1}{c}{ Aspects } & $\mathbf{2 0 1 1}$ & $\mathbf{2 0 1 2}$ & $\mathbf{2 0 1 3}$ & $\mathbf{2 0 1 4}$ & $\mathbf{2 0 1 5}$ \\
\hline Vision and strategy (1) & 0 & 0 & 1 & 1 & 1 \\
Material (2) & 0 & 0 & 1 & 1 & 1 \\
Energy (2) & 1 & 2 & 2 & 1 & 2 \\
Water (3) & 1 & 1 & 1 & 0 & 0 \\
Landscape and biodiversity (4) & 1 & 1 & 3 & 2 & 3 \\
Emissions (4) & 0 & 3 & 3 & 3 & 3 \\
Effluents and waste (5) & 1 & 1 & 1 & 3 & 1 \\
Compliance (1) & 0 & 0 & 0 & 0 & 0 \\
Transport (1) & 0 & 1 & 1 & 1 & 1 \\
Overall (1) & 0 & 0 & 0 & 0 & 0 \\
Supplier environmental & 0 & 0 & 0 & 0 & 0 \\
assessment (1) & 0 & 0 & 0 & 0 & 0 \\
Environmental grievance & 2 & 2 & 3 & 2 & 2 \\
mechanisms (1) & 2 & 2 & 2 & 1 & 2 \\
Education (6) & 2 & 2 & 2 & 2 & 2 \\
Research (5) & $10(24 \%)$ & $15(37 \%)$ & $20(49 \%)$ & $17(41 \%)$ & $18(44 \%)$ \\
Community engagement (4) & & & & \\
Total (41) & & & & 0 \\
\hline
\end{tabular}

Note: the number in the bracket refers to the No. of metrics in the aspect; the percentage in the bracket represents the weighting as to the number of reported metrics to the possible maximum (41) for any individual year.

Another finding is that the size of the report became larger over time, from 6 pages in 2011 to 13 pages in 2015, although there was a decrease (to 6 pages) in 2014 (refer to Figure 1). The finding is consistent with the overall upward trend for disclosures. Nonetheless, it is surprising that the university performs the best in 2013 as the size of the report is 8 pages smaller than the size of the year 2015 report (13 pages). The result reveals that the larger size of the report does not represent more disclosures in terms of reported metrics. Yet the university reports more details for the disclosed metrics in 2015, as compared with the 2013 report. In effect, the size of 13 pages, representing the largest size in the period, is hard to be deemed large and comprehensive. Moreover, the overall low level of reporting performance suggests that the report should be significantly expanded to include more environmental or more broadly sustainability related metrics. In this respect, some relevant guidelines, such as GRI and its SSPA, would be helpful. 


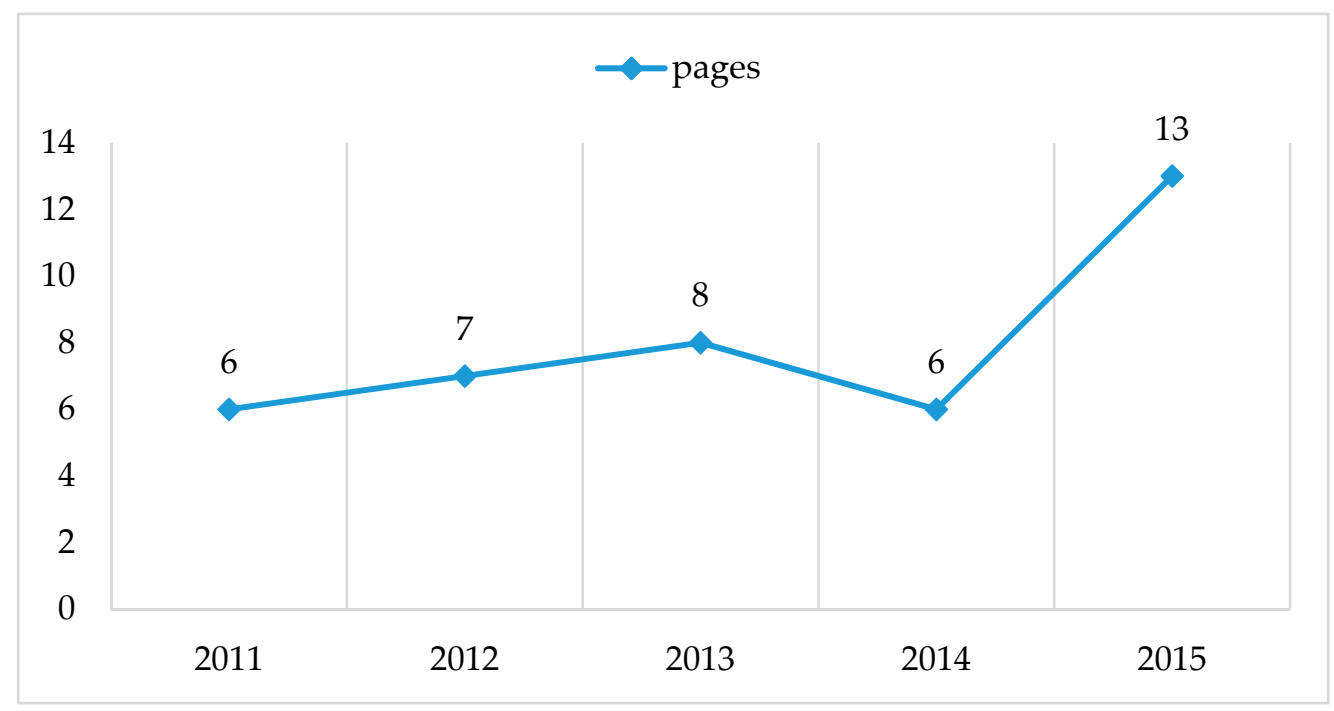

Figure 1. No. of pages of the sustainability report.

Further, we notice that the report has become more formal and standardized since 2012, although the disclosures are not detailed. The report often consists of such sections as "introduction", "what are we measuring and how are we doing" (or called "sustainability indicators"), and "sustainability progress". In the section of "what are we measuring and how are we doing", it often illustrates the core sustainability indicators recognized by the university in table form. It is noted that the majority of reported indicators are environmentally related. The section of "sustainability progress" is the main body of the report. It often focuses on such environmental aspects as "carbon reporting", "landscape \& biodiversity", "waste \& recycling", "transport", and "environmental/sustainability related curriculum and research".

On the basis of the findings, it is evident that the report is environmentally focused, and seems to be an environmental report rather than a holistic sustainability report, owing to the minimal economic and social disclosures. On the other hand, this may reflect the perception of the university, or more specifically, the sustainability office, that sustainability is principally concerned with environmental issues, while it does not provide a clear definition of "sustainability" in the report to indicate the scope of its reporting. As a staff member in the sustainability office claims that "... our focus is environmental when preparing the report, because we believe that it is the most relevant to sustainability". In effect, many universities in the world have a similar focus and views regarding sustainability and reporting $[1,25,26]$. There is a definite need for the higher education organizations to extend the principles of sustainability and the scope of relevant reporting, so as to improve the transparency of the organization, as well as meet the ever-growing information needs of a variety of stakeholders [3].

It is interesting that the university reports the key results of its self-conducted sustainability survey from 2011 to 2013 . The survey primarily investigates the perceptions of UC students on: "relative importance of sustainability issues to UC community", "relative importance of knowledge of sustainability practice for future employment", "impressions of UC's sustainable practice", "interest amongst students in a stronger sustainability focus to their studies or research", "level of sustainable practice amongst students in their personal lives", and "requisites for improving sustainability practice in colleges and service units" [19-21]. The survey results show that UC students view sustainability to be critical for their studies, personal lives, and the future. As a student interviewee states "the sustainability survey by university increases the awareness of us about sustainability, and facilitates the spreading of the concept of sustainability among fellow students on campus".

Also, the university reports the recipients of its internal "sustainability awards" and "summer sustainability scholarship" and the title of relevant projects from 2011 to 2013, which are principally 
presented to academic staff and students. These awards reveal that UC assigns great importance to the environment and sustainability, and moreover encourages and supports its staff and students to conduct sustainability related research. The research projects are valuable as the sustainability office states "many research topics provided useful, practical insights into how to progress sustainability practices at UC, plus engage with staff and students" [22] (p. 6). Nonetheless, the university did not conduct the annual sustainability survey as well as the presentation of sustainability awards and summer scholarship in recent years, it is reported that this is due to the shortage of human resources. It is expected that the university would reinitiate the activities once the resources are available.

More specifically, the university performs well in the following environmental related aspects, such as "energy", "landscape and biodiversity", and "effluents and waste", since some metrics of these aspects are frequently reported in the report during the period. Two aspects, comprising "emissions" and "transport", have good performance in spite of a one-year absence in 2001. It is noted that the university is the first university in the southern hemisphere and the only university in New Zealand to achieve CEMARS accreditation (Certified Emissions Measurement and Reduction Scheme). As the university claims that:

"The university of Canterbury meets the requirements of CEMARS certification having measured it greenhouse gas emissions in compliance with ISO 14064-1: 2006, and committed to managing and reducing it greenhouse gas emissions in respect of the operational activities of its organization." [20] (p. 4)

There has been an electronic link in the report since 2012 that can direct the reader to access the detailed information with respect to carbon emissions of the university. As implied in the report, detailed disclosures for carbon emissions are not a common practice for universities. UC has done an excellent job in this regard.

As a public organization providing the service of higher education, universities have great responsibilities to educate future leaders of society to think and behave in a sustainable manner through a wide range of teaching programs and research projects. The university does disclose a number of sustainability/environmental related courses and research projects in the report. The university asserts that it is committed to improving and expanding the courses and projects, including the introduction of new sustainability related degree programs. It was observed that the university performs impressively for the reporting of some metrics in the aspect of "community engagement". For instance, community engagement events include Okeover Stream Community Engagement Project to improve storm water quality and stream health, bringing local secondary school students for a sustainability tour of the campus, Fair Trade Fortnight, Eco Week, and so forth [20-22].

These activities strengthen the university's connection with local communities, and consequently improve the relationship with them. It would be helpful for the university to gain support from the community where they operate. Furthermore, we notice that the university sustainability office uses some social media, such as blogs, a newsletter, and Facebook, to interact with stakeholders in regards to sustainability issues. The use of social media would facilitate the participation of various stakeholders in the university's sustainability related activities, and consequently improve the communication between the university and the community as to its efforts towards sustainability. The application of social media is a trend for organizations to report sustainability related initiatives and efforts in the current information age. In effect, some universities, including UC, have devised a particular webpage for sustainability on the website, which covers a large amount of sustainability related information.

For the quality of reported information, we are unable to find any monetary related disclosures in the report. Table 4 and Figure 2 demonstrate the status in this regard for the five years. It can be found that "physical + descriptive" is the most commonly used reporting style for disclosed information, accountable for more than 50\% of disclosures from 2012 to 2015 . Purely "descriptive" disclosures rank the second while the simply "physical" disclosures are the least in general. These three types of disclosures are all that we can catch in the current study. The absence of monetary related disclosures 
suggests that the quality of the UC sustainability report is not high. In essence, it is a narrative based report, albeit it includes some physical disclosures, such as percentage, Kwh, tonnes, and litres. The result is not surprising because of the generally small size of the report, as well as the non-reporting of social and economic disclosures that often consist of a number of monetary terms.

Table 4. Type of sustainability information (No.).

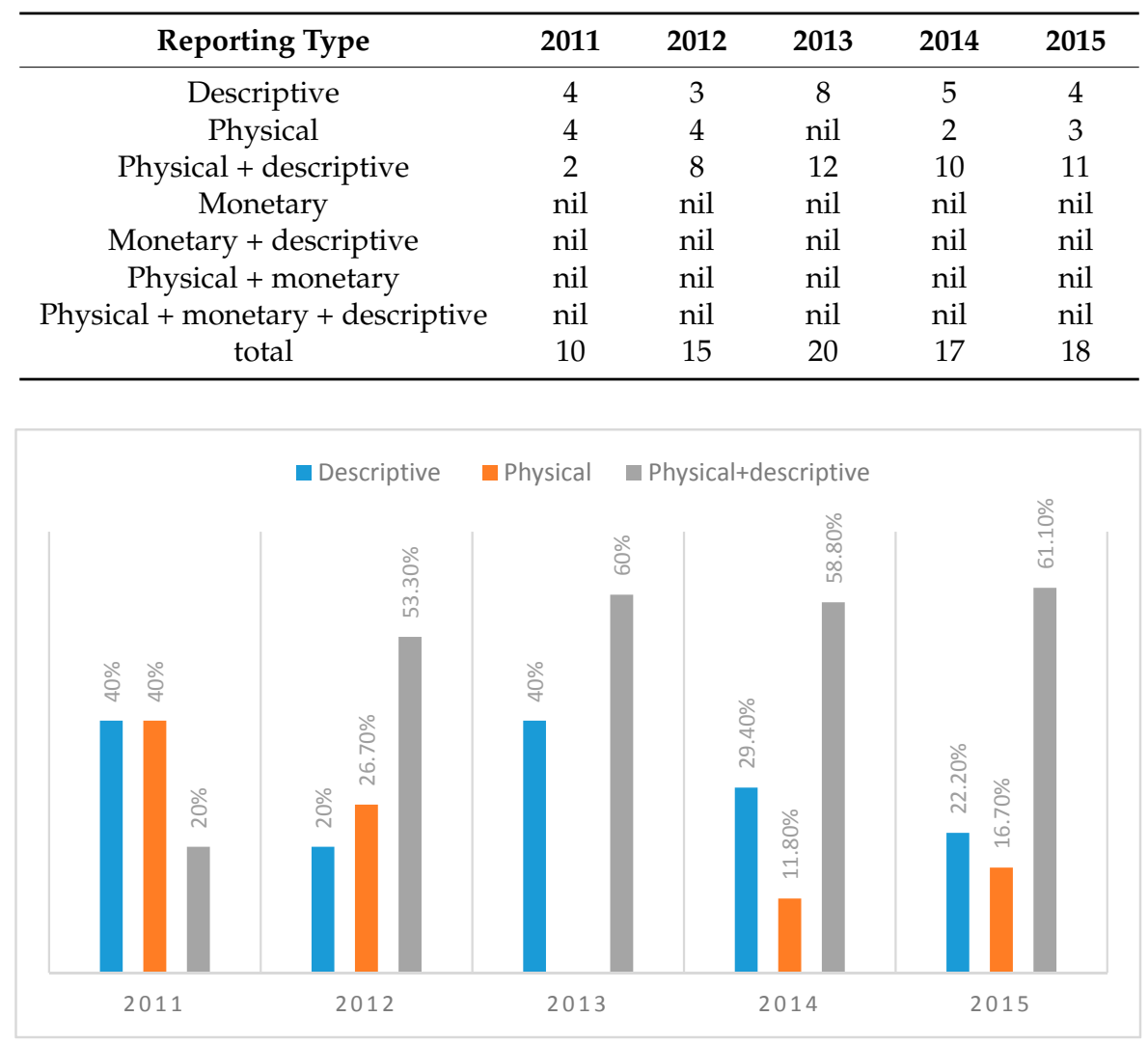

Figure 2. Type of reported information (\%).

\section{Summary and Conclusions}

This study examines the case of sustainability reporting at a New Zealand university from a longitudinal perspective. It adds to the extant literature in the New Zealand context, which is often considered to be one of the most sustainable nations in the world. We collected data from the 'sustainability' report prepared by the university sustainability office, albeit its primary focus is environmentally related. The results indicate that there is a generally upward trend for the reporting of environmental related information in the investigated period although the reported metrics are limited. We notice that the university does not follow any reporting guidelines for its reporting. In addition, we observe that no monetary related disclosures can be found in the report and that the majority of disclosures are narrative despite some physical disclosures.

On the basis of the results and findings, we conclude that the current level of sustainability reporting for the university is still in its early stage, as suggested by Ceulemans et al. [2]. However, as we consider that it is the only university to publish an external stand-alone sustainability report in a nation that is recognized as one of the most sustainable nations in the world, we would argue that it has been a pioneer for such reporting practices in the country, or even worldwide. According to GRI, the number of universities issuing a stand-alone sustainability report is currently not significant, although there is an increasing trend [27]. Thus, sustainability reporting is not a common practice in the higher education sector. The lack of specific reporting guidelines for the sector may be a major 
factor contributing to the status, while we do believe that most universities in the world attach great importance to sustainability and its reporting.

Taking the case of this study as an example, UC pays much attention to sustainability, although its reporting is not as good as expected. As indicated in the report, it has a ten-year sustainability strategy between 2012 and 2022, "which breaks sustainability planning into short, medium and long term objectives" [21] (p. 2). Three principles are identified to underpin the strategy, comprising of "being sustainable is economically sensible", "being sustainable will help us retain and attract quality students, staff and funding", and "we have an obligation to be good stewards of our environment, in line with the principle of Kaitiakitanga" (UC sustainability strategy: 2012-2022). Moreover, the university claims that its sustainability related initiatives under the strategy would meet the requirements of at least two of three principles in the ten-year period.

From the ten-year strategy, as well as the findings in the study, we do believe that the university does have a strong commitment as to sustainability, and would like to improve the reporting of relevant issues. It is consistent with the legitimacy theory, which suggests that the reporting of information demanded by society is a useful medium for organizations to obtain the status of "legitimacy". Sustainability reporting in a stand-alone sustainability report by UC would be a beneficial way to be perceived as a socially responsible organization by society, and consequentially legitimize its operations in the community where it operates [16-18]. Of course, as we indicated earlier in the paper, there is still big room for UC to improve the state of its sustainability reporting. That is, to achieve the status of "legitimacy", UC still has a long way to go. In the light of this, how to improve the level of sustainability reporting for $\mathrm{UC}$, and for the higher education sector in general, remains a big question. We believe that the following suggestions may provide some solutions for it.

First, the university could employ GRI and its SPAA guidelines as a basis, as well as combine the specific characteristics of its own organization, to undertake relevant reporting, particularly to improve social and economic reporting, as well as monetary reporting. Furthermore, organizations in the higher education sector should strengthen collaborations with each other in developing specific guidelines applicable to the sector. In addition, we could turn to GRI for specific guidelines for the higher education sector since it has done the job for other specific sectors, such as finance and energy. Last but not the least, the university could apply the existing information and communication technologies, such as online forums, newsletters, and social media (i.e., Facebook, Twitter, and Youtube), to disseminate and communicate sustainability related information to various stakeholders and the community in a timely manner.

Since this study focuses on one case university only, future research could be extended in the following ways. First, we can expand the sample size to include universities that issue a stand-alone sustainability report currently in the world, so that we are able to obtain some insights regarding the status of sustainability reporting from an international perspective. Second, we can employ a questionnaire survey to investigate the perceptions of students, academics, specific sustainability officer, and the university management with regard to sustainability and relevant reporting in the New Zealand higher education sector. Lastly, since a number of universities around the world have applied information and communication technologies to report their sustainability related initiatives in the recent decade, future research can be conducted to examine the status of online sustainability reporting in a variety of national contexts.

Acknowledgments: The authors appreciate the constructive comments from the two reviewers in improving the quality of the paper. Harun Harun gratefully acknowledges the financial support provided by the Faculty of Business, Governance and Law, University of Canberra for this project (No. 7145). Yi An acknowledges the financial support provided by National Social Science Foundation of China (No. 15BJL021) and Provincial Social Science Foundation of Shandong (No. 16CKJJ13).

Author Contributions: Yi An and Harun Harun designed the research and wrote the paper; Howard Davey guided the research and revised the paper.

Conflicts of Interest: The authors declare no conflict of interest. 


\section{References}

1. Alonso-Almeida, M.M.; Marimon, F.; Casani, F.; Rodriguez-Pomeda, J. Diffusion of sustainability reporting in universities: Current situation and future perspectives. J. Clean. Prod. 2015, 106, 144-154. [CrossRef]

2. Ceulemans, K.; Lozano, R.; Alonso-Almeida, M.M. Sustainability reporting in higher education: Interconnecting the reporting process and organizational change management for sustainability. Sustainability 2015, 7, 8881-8903. [CrossRef]

3. Sánchez, R.G.; Bolívar, M.P.R.; Hernández, A.M.L. Are Australian universities making good use of ICT for CSR reporting? Sustainability 2015, 7, 14895-14916. [CrossRef]

4. Townsend, J.; Barrett, J. Exploring the application of Carbon footprinting towards sustainability at a UK university: Reporting and decision making. J. Clean. Prod. 2015, 107, 164-176. [CrossRef]

5. Adams, C.A. Sustainability reporting and performance management in universities: Challenges and benefits. Sustain. Account. Manag. Policy J. 2013, 4, 384-392. [CrossRef]

6. Guthrie, J.; Parker, L. Corporate social reporting: A rebuttal of legitimacy theory. Account. Bus. Res. 1989, 19, 343-352. [CrossRef]

7. Gray, R.; Kouhy, R.; Lavers, S. Corporate social and environmental reporting: A review of the literature and a longitudinal study of UK disclosure. Account. Audit. Account. J. 1995, 8, 47-77. [CrossRef]

8. Al-Tuwaijri, S.A.; Christensen, T.E.; Hughes, K.E. The relations among environmental disclosure, environmental performance, and economic performance: A simultaneous equations approach. Account. Organ. Soc. 2004, 29, 447-471. [CrossRef]

9. Islam, M.A.; Deegan, C. Motivations for an organization within a developing country to report social responsibility information: Evidence from Bangladesh. Account. Audit. Account. J. 2008, 21, 850-874. [CrossRef]

10. De Villiers, C.; Low, M.; Samkin, G. The institutionalization of mining company sustainability disclosures. J. Clean. Prod. 2014, 84, 51-58. [CrossRef]

11. Guthrie, J.; Farneti, F. GRI sustainability reporting by Australian public sector organizations. Public Money Manag. 2008, 28, 361-366. [CrossRef]

12. Goswami, K.; Lodhia, S. Sustainability disclosure patterns of South Australian local councils: A case study. Public Money Manag. 2014, 34, 273-280. [CrossRef]

13. Ball, A.; Grubnic, S. Sustainability accounting and accountability in the public sector. In Sustainability Accounting and Accountability; Unerman, J., Bebbington, J., O'Dwyer, B., Eds.; Routledge: London, UK, 2007.

14. Global Reporting Initiative (GRI). Sector Supplement for Public Agencies: Pilot Version 1.1 with an Abridged Version of the GRI 2002 Sustainability Reporting Guidelines; Global Reporting Initiatives: Amsterdam, The Netherlands, 2005.

15. Sciulli, N. Influences on sustainability reporting within local government. Int. Rev. Bus. Res. Pap. 2011, 7, 282-291.

16. Deegan, C.; Samkin, G. New Zealand Financial Accounting; McGraw-Hill: North Ryde, Australia, 2009.

17. Suchman, M.C. Managing legitimacy: Strategic and institutional approaches. Acad. Manag. Rev. 1995, 20, 571-610.

18. Lindblom, C.K. The implications of organizational legitimacy for corporate social performance and disclosure. In Proceedings of the Critical Perspectives on Accounting Conference, New York, NY, USA, 13-15 June 1994.

19. University of Canterbury. UC Sustainability Report 2011; University of Canterbury: Christchurch, New Zealand, 2011.

20. University of Canterbury. UC Sustainability Report 2012; University of Canterbury: Christchurch, New Zealand, 2012.

21. University of Canterbury. UC Sustainability Report 2013; University of Canterbury: Christchurch, New Zealand, 2013.

22. University of Canterbury. UC Sustainability Report 2014; University of Canterbury: Christchurch, New Zealand, 2014.

23. University of Canterbury. UC Sustainability Report 2015; University of Canterbury: Christchurch, New Zealand, 2015.

24. Guthrie, J.; Abeysekera, I. Content analysis of social, environmental reporting: What is new? J. Hum. Resour. Costing Account. 2006, 10, 114-126. [CrossRef] 
25. Fonseca, A.; Macdonald, A.; Dandy, E.; Valenti, P. The state of sustainability reporting at Canadian universities. Int. J. Sustain. High. Educ. 2011, 12, 22-40. [CrossRef]

26. Lozano, R. The state of sustainability reporting in universities. Int. J. Sustain. High. Educ. 2011, 12, 67-78. [CrossRef]

27. Global Reporting Initiative. Sustainability Disclosure Database. Available online: http://database. globalreporting.org/ (accessed on 8 December 2016).

(c) (1)

(C) 2017 by the authors. Licensee MDPI, Basel, Switzerland. This article is an open access article distributed under the terms and conditions of the Creative Commons Attribution (CC BY) license (http:/ / creativecommons.org/licenses/by/4.0/). 